\title{
Living (in) the city centre, neoliberal urbanism, Engage Liverpool and citizen engagement with urban change in Liverpool, UK
}

\author{
Janet Speake $^{\mathrm{a} *}$, Maria Pentaraki $^{\mathrm{b}}$ \\ a Liverpool Hope University, $U K$ \\ $b$ Queen's University, Belfast, $U K$
}

The critical current of urban regeneration scholarly research focusses on neoliberal urbanism. In concentrating on the neoliberal economic, business and financial dimensions as driving forces behind urban change and regeneration, the human dimension of city centres and city centre living is frequently overshadowed. This paper explores the human dimension through the example of Engage Liverpool, a citizen and neighbourhood organisation. This paper investigates citizen engagement with urban development in the setting of the city centre and central waterfront in Liverpool. The paper argues that despite the dominance of global neoliberal forces within regeneration, citizen and neighbourhood organisations such as Liverpool Engage may have the potential to facilitate citizens' participation as change makers in urban (re)development.

Key Words: Urban development, citizen engagement, citizen voices, neighbourhood, Liverpool, Engage Liverpool.

Article Info: Received: January 23, 2017; Revised: May 5, 2017; Accepted: May 20, 2017; Online: May 25, 2017.

\section{Introduction}

Within the context of contemporary neoliberal capitalism, financial and economic forces are the dominant drivers of city change and regeneration, the human dimension is often side-lined. It is important that all of the factors contributing to city centre regeneration are considered and that the multiple urban voices are told, shared and heard. This paper explores these themes in

\section{* Corresponding author}

Address: Liverpool Hope University, Department of Geography and Environmental Science, Hope Park, Liverpool, L16 9JD, UK

Phone: +44 (0)1512913594 | Email: speakej@hope.ac.uk

(C)2017 Human Geographies; The authors

(c) (i) This work is licensed under a

Creative Commons Attribution 4.0 International License. DOI:10.5719/hgeo.2017.111.3 
the setting of the rapidly changing city centre and central waterfront in the city of Liverpool, UK, at a time when supra national, governmental and academic interests in this city and in many others globally are being drawn towards the human dimensions and issues associated with living in the neoliberal and transformed city centre.

The paper is structured as following. It first sets the current context for urban transformations within the setting of neoliberal capitalism and discusses increasing global and local recognition being given to the importance of the multiple and real voices of 'social capital' in the making of sustainable, liveable city centres. Second, it reports on the character of recent city centre change in Liverpool. Third, it explores the role of the residents' association Engage Liverpool in facilitating citizens' participation as urban change makers and then narrates perspectives of Liverpool city centre residents on living in the city centre before presenting the conclusions of the research.

\section{Transforming city centres within neoliberal capitalism}

The regeneration of Liverpool and of many other cities globally is clearly positioned within the context of the transformation of cities in which the dominant forces in shaping and transforming cities is the neoliberal economic environment, the 'entrepreneurial city' (Harvey, 1989, 2005; Hall and Hubbard 1998; Jessop and Sum, 2000; Ward, 2003; Boddy and Parkinson 2004; Fainstein, 2010; Brenner et al., 2011), and the use of state power in the promotion of business and finance (Fainstein, 2010, 2016; Halbert and Attuyer, 2016). Investment in cities and in their transformation is largely directed towards business rather than social capital (Buck et al., 2005; Brenner et al., 2009, 2011; Marcuse et al., 2011; Harvey, 2012; Sassen, 2012). In their quest for competitive advantage within neoliberal capitalism, cities tend to emphasise the built and commercial environment (Fainstein, 2001; Buck et al., 2005; Knox, 2011). City imagineers and marketeers create glossy images to portray cities as vibrant, dynamic economic entities with contemporary architecture, cutting-edge urban design and creative, dynamic business (Avraham and Kettner, 2008; Gehl, 2010; Knox, 2011; Speake, 2016). This commodified and financialised behaviour of is driven by the affluent and political elites and is reflected in the preponderance and high visibility of large, property-led city centre and waterfront regeneration schemes (e.g. Oatley, 1998; Miles, 2007; Garcia et al., 2010; Smith, 2012; Smith and Soledad Garcia Ferrari, 2012; Speake, 2016).

Many of these 'top-down' initiatives have transformed the areas in which they are located, and the economic and spatial impacts of substantive culture-led property revitalisation schemes have been frequently reported (Gold and Gold, 2005, 2007; Plaza, 2006; Aitchison et al., 2007; Jones, 2007; Smith, 2012). This is the case, even in context of leisure and culture-led urban revitalisation, and recent moves towards community and neighbourhood regeneration (e.g. Jacobs and Dutton 2000; CLG, 2006; Cochrane, 2007; Scott, 2008; Tallon, 2010; Brudell and Attuyer, 2014). Within neoliberalism and its emphasis on financialised, commercialised interest, property and built environment diverse human experience have been subordinated and subsumed (e.g. Scharenberg and Bader, 2009). 
Thus, in this context relatively little is known about the relationships between the planned transformation of a locality undertaken by agents of change as architects and urban designers and the realities of living (in) the city centre (Waley, 2006; McNeill, 2011; Gehl, 2011) experienced by citizens. This is a significant gap, especially since most cities transforming within neoliberal capitalism have utilised residential property development as the main commercial driver.

\section{Living (in) the city centre}

Within neoliberal capitalism, humanity and relationships, community and voice, and neighbourhood and connections are subsumed by emphases on financial opportunity, aspiration and urbanity. People and their everyday lives feature less in mediatised projections of the contemporary city centre than, for example, sharp, contemporary urban design and the glamorised place promotion. However, the everyday experiences of living (in) the city rather than the aspirational imagery favoured by developers, are under the political and academic spotlight (Gehl, 2011; Smith, 2012). This is because city centres, rather than being (and perceived as) locations dominated by commercial activity, capital accumulation and paid employment are becoming (and perceived as) increasingly complex places in which work, home and life intermingle.

This has meant that city centres now have and experience "complex social realities" Marquardt et al. (2013, p. 1552). As such, matters of everyday living are a challenge in many city centres because people are attempting to live their (ordinary) daily lives in a different (extraordinary) setting - the revitalising neoliberal city centre. It is an 'extraordinary' setting in the sense that many living spaces in city centres have been created in places (such as warehouses and quaysides) which were not formerly lived in and have no long established tradition of residential community. The oldest of most of these are barely more than 30 years old. Frequently, these residential developments are not well embedded or supported by community or neighbourhood initiatives (Jones, 2003; Davidson and Lees, 2005; Colomb, 2007), mostly because these too have to be created from scratch.The UK is not alone in this respect, there are parallels elsewhere, Battery Park City, Manhattan (Fainstein, 2010), the waterfront in Boston (Heeg, 2011), Bilbao (Bianchini and Ghilardi, 2004, Fjord City, Oslo (Hofseth, 2008) and HafenCity, Hamburg (Bruns-Berentelg, 2011; HafenCity Hamburg 2012). All of them, to varying degrees, have confronted the challenge of creating and developing neighbourhood and community identities, fostering community cohesiveness and improving liveability and experiences of living (in) the city. At the same time, a number of studies (Marcuse et al., 2011; Bowland et al., 2017) have raised questions such as on the one hand, who profits from the city and whose experience of living in the city has been encouraged and enhanced and, on the other hand, who is now excluded and displaced. In addition to these studies others such as Seo (2002), Lees $(2007,2008)$; Howley et al. (2009), Unsworth (2009), Foord (2010) Howley (2010) point to the regenerating city centre as having a complex differentiated mix.

Moreover, there is clear evidence that careful design and social vision can pull people (and communities) together to encourage senses of shared citizen- 
ship (Roberts, 2009; Rogers and Power, 2000; Gehl, 2010; Knox, 2011; New Urbanism, 2014), and that the voice of the citizen is crucial to regenerating cities (Scharenberg and Bader, 2009; Gehl, 2010; Ferilli et al. 2016).

There are many studies across the social sciences that report on the contestation, struggles and change making 'from below' by grassroots citizens groups. Examples in the urban regeneration and planning literature include citizen activism in Mediaspree, Berlin, (Scharenberg and Bader, 2009), in Dublin (Brudell and Attuyer, 2014; Attuyer, 2015) and Melbourne (Legacy, 2016). The social studies and community literature includes Mannarini and Talò (2013) and Antonini et al. (2015). In social work there has been much reporting on responses of citizen action generally for example, Kirst-Ashman and Hull (2001), in Ireland (Meade, 2005), in Pittsburgh (Ohmer, 2007) and in Greece (Pentaraki and Speake, 2015; Teloni and Adam, 2016). It becomes clear from this evidence that even though citizen action may operate within the imposed 'top down' context of neoliberalism, it can operationalise Gramsci's conceptualisation of change 'from below' (Gramsci, 1971) through challenges to imposed dominant neoliberal forces and contributions to building a better (urban) world.

The paper will next present the main characteristics of the transformation of Liverpool city centre and waterfront before moving on to consider the role of Engage Liverpool in harnessing citizens' voices and contributions to urban change.

\section{Living (in) the city centre: Liverpool city centre and waterfront}

This section sets the current context for city centre living in Liverpool within the current politico-economic context of rapid transformation urban transformation and change under neoliberalism.

In the early years of the 21 st century Liverpool rapid urban revitalisation has been economically and functionally transformative, essentially top-down led (Geddes et al., 2007; Cocks, 2013) and largely focussed on the development and (re)regeneration of the city centre. The revival of the city centre and waterfront following severe post-industrial decline in the 1970s and 1980s is well charted in an extensive academic literature (Couch and Dennemann; 2000; Couch, 2003; Speake and Fox, 2006; Biddulph, 2010; Couch and Cocks, 2012; Sykes et al., 2013). Predominant drivers for this revival have been property and culture led with much impetus for the completion of existing projects and the creation of new ones being generated by Liverpool's status as European Capital of Culture (ECoC), 2008 (Connelly, 2013). Since then the focus has been largely on cultureled and increasingly financialised regeneration initiatives particularly the burgeoning of residential property development.

The intense financialisation of residential property-led regeneration is characteristic of contemporary neoliberal urban development and represents the latest stage in the development of dwellings in the city centre and waterfront (Couch and Dennemann, 2000; Morris and Speake, 2010; Nevin, 2010). These reurbanisation processes (Couch et al., 2009; Nevin, 2010; Cocks and Couch, 2012) have been similar to those experienced in large metropolitan city centres elsewhere (Couch, 1999; Seo, 2002; Bromley et al., 2007; Allen, 2007; Howley and Clifford, 2009; Rae, 2013). 


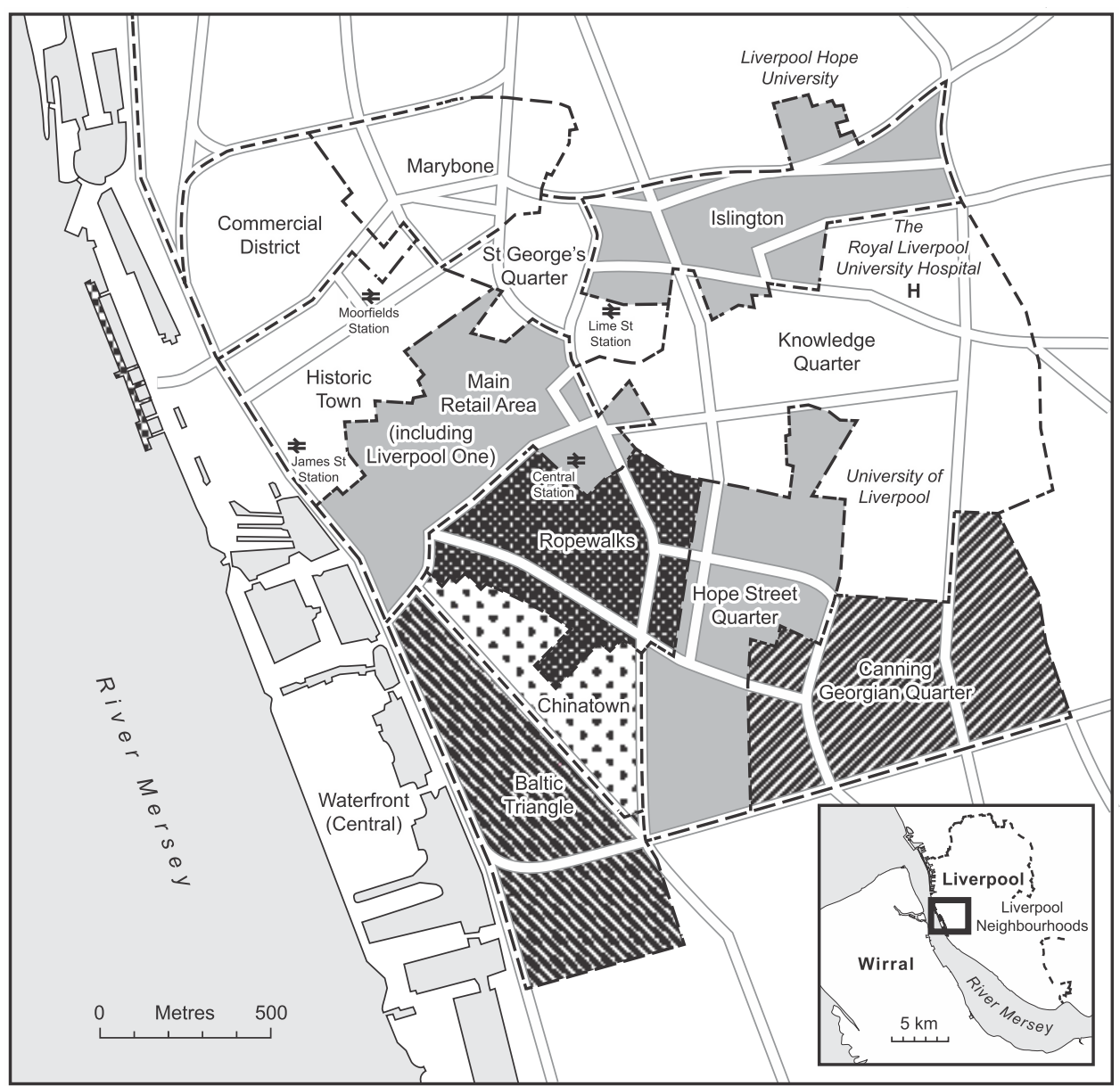

Figure 1. Neighbourhoods in Central Liverpool After: Engage Liverpool (2014a)

In Liverpool city centre, the housing stock predominantly comprises one and two bedroom apartments that are generally new-build, or in refurbished former industrial premises and warehouses. These are located in traditionally nonresidential areas, for example in the Ropewalks and Baltic Triangle neighbourhoods (Couch and Dennemann, 2000; Couch et al., 2009; Liverpool Vision and Liverpool City Council, 2010). Overall, city centre properties tend to be lived in by smaller households, generally without children (Couch et al., 2009). This expansion of residential accommodation is mirrored in the marked increase in the residential population of Liverpool's city centre and waterfront from 2,300 in 1991, to 23,350 in 2010 (Liverpool Vision, 2010) and then to 33,540 living in 14,000 residences in 2016 (Liverpool Vision, 2016) and representing 7\% of the city's total population of 473,073 in 2016 (Liverpool City Council, 2016) with projections for further growth. These areas of rapid social and cityscape changes provide the locational focus of this article (Figure 1).

This residential (re)scripting and revitalisation along with wider economic reinvigoration has provided the city with a platform for considerable reimaging and (re)branding - to project the city as 'edgy', forward-looking and cosmopoli- 
tan, and to counter long-standing and pervasive (often media) representations as declining and threatening (Wilks-Heeg, 2003; Hudson and Hawkins, 2006; Boland, 2008; 2010). Place marketing initiatives and campaigns such as 'It's Liverpool' incorporating 'I'm Liverpool', launched in 2011 (It's Liverpool, 2014), reflect Liverpool's resurgent confidence and reaffirm the distinctive, strong senses of place identity and individual and collective sentiment held by many people who live and work in the city (Boland, 2010). This sense of identity comes from collective reactions and responses to major economic and social challenges (Boland, 2008, 2010; Frost and Philips, 2011) along with pride in the city's many achievements, for example in sport and music (e.g. Du Noyer, 2002; Cohen, 2007). This identity is under pinned by events in the city as well as by tightly bound attachments to locality. Such interplays between place and people have created a very distinctive city with a range of complex intertwined socioeconomic and cultural specificities (e.g. Meegan, 2003; Boland, 2008; 2010) which provide context for the current innovative approaches to enhancing community engagement in city centre development that are explored in the next section.

\section{Living (in) the city centre: Engage Liverpool}

Despite the top-down approach through which Liverpool city centre has been and continues to be transformed along neoliberal lines, there are grassroots citizens groups which are part of city centre transformation an example of which is Engage Liverpool, a large grassroots residents' initiative in Liverpool city centre. As a conduit for the voices of an estimated 33,540 people (Liverpool Vision, 2016) who reside in the Liverpool city centre and central waterfront locations (Figure 1) Engage Liverpool offers opportunities for alternative voices to be listened to (Engage Liverpool, 2014b). In fact, Engage Liverpool itself has an important and to-date, under-reported, story to tell of the encouragement and facilitation of city centre residents' voices.

Engage Liverpool is one the largest residents' network in the UK and is playing a major role in community and neighbourhood capacity building. While not unique in its broad and challenging remit, it is unique in terms of practice. In 2008, the Engage Liverpool partnership was established by Liverpool City Council, The Federation of Liverpool Waterfront Residents Associations, and Liverpool City Centre Leaseholders' Federation with support from the Plus Dane Group (Liverpool Vision and Liverpool City Council, 2010). In 2013, it became a Community Interest Company (CIC). The Mission Statement of Engage Liverpool is "To improve the quality of life for people living in Liverpool City Centre and Waterfront neighbourhoods by empowering residents through aspirational engagement and action to bring about positive transformation and progress" (Liverpool Engage, 2017).

Most of the city centre and waterfront's 14,000 residents (Liverpool Vision, 2016) are in locations that are not traditionally residential. This includes historic waterfront property at Albert Dock, Wapping Dock and Waterloo Dock as well as contemporary riverside apartments like those at Mann Island. A little further inland, the converted warehouses and purpose-built apartments of Rope Walks create a distinctive living space (Couch and Dennemann, 2000; Speake and Fox, 
2006) and further residential development in Liverpool One (Littlefield, 2009) and the recently revitalising LGBT Stanley Street Quarter (Liverpool City Council, 2011) widens the geographical and cultural reach of Engage Liverpool.

Engage Liverpool creates opportunities for people to 'embed' into their living spaces and foster identity and senses of belonging, which is important since many people live in locations which have not been traditionally residential. It also maintains that it is vital for people living in Liverpool to enjoy being in Liverpool. This is done by encouraging residents to engage with each other to discuss issues to do with everyday experiences of living (in) the city. This is done virtually through the Engage Liverpool website, blogs and tweets (Engage Liverpool, 2014b) and face-to-face meetings at a range of locations from individual apartment blocks to seminar series and conferences held in major city centre venues (Engage Liverpool, 2014b). A successful dimension to its work has been the organisation of the 'Blockheads' seminar series which has provided training for the management of apartments. One of the main motivations for Engage Liverpool has been to harness residents' voices and actions and to project these elements of social visioning to a wider audience and to attempt to input more vocally and effectively into policy formulation and planning.

Through Engage Liverpool and Liverpool Vision's 'City Conversations', city centre residents have been able to contribute to the developmental discussions for the Liverpool City Centre Strategic Investment Framework (Liverpool Vision, 2012) in which the city's strategic direction for development for the next 30 years is outlined. People lie at the heart of the envisioning for the city's future. Implementation of the Strategic Investment Framework will take the population of the city centre to over 42,000 , which will be the largest of any city in the UK. The document reports that: 'it is vital that the quality of life of the residents is at the forefront of this expansion, creating high quality developments and spaces, which take into account the importance of human interaction' (Liverpool Vision, 2012, p. 28).

Key to this is the evolution of 'distinctive neighbourhoods' a theme devised to 'consolidate and develop' the distinctiveness of neighbourhood. These include Waterfront, Liverpool One, Ropewalks, Baltic Triangle, Marybone and Canning Georgian Quarter. In addition, it seeks to grow new distinctive neighbourhoods in Historic Downtown and Islington (Liverpool Vision, 2012, p. 28). The underpinning concept is to create a more diverse residential population, incorporating multiple housing forms in both new build and 'repurposed' buildings in the historic downtown (Liverpool Vision, 2012, p.90).

Quality of place goes hand in hand with quality of life and the Strategic Investment Framework stipulates that new development must be of the highest build quality and design, be well managed and encourage social interaction so that residents can 'fully enjoy their city living experience' (Liverpool Vision, 2012, p. 90). In 2013 a £10,000 award was made to Engage by the UK's 'Big Lottery Awards for All' to fund the Baltic Triangle Pilot Project with the aim to develop a sense of neighbourhood through connecting residents with each other over a six-month period using social media and face-to-face encounters. Since then it has also been successful in obtaining funding from the same source for its Blue-Green Liverpool Project which has involved local citizens in formulating proposals for a greener, sustainable city centre and waterfront. 
Given this steer towards people and the quality of their everyday lived lives in the city centre, it is evident that Engage has a unique role in being able to gather and harvest the views and opinions of city centre residents and input them to policy making. In many ways it provides a very good example of a way to 'innovate from within' (Holden and Scerri, 2013, p. 452), in terms of developing sustainable and liveable urban life.

\section{Living (in) the city centre: Citizens' voices}

People have their own experiences and stories of city life that can enrich understanding of urban living and urban change. However, these narratives are often 'told', but are seldom 'heard'. Furthermore, these stories and experiences are important as people present them as personal urban encounters, but do not necessarily recognise the importance of their narratives in developing an understanding of living in (for most of the UK at least) a new environment - the regenerating city centre in which traditionally non-residential locations have become places in which people now reside and live.

In an environment of social visioning, and the quest for (re)animation of neighbourhoods and the enhancement of city centre living the voices (polyvocality) of residents are rarely 'heard'. For Engage Liverpool, this is a key activity, enabled in settings which encourage multi-way global-local, global-city and local-local dialogue. Residents are able to participate in face-to-face discussions and social media interactions in which their role as city-changers is activated. A digital presence, with recordings of seminars, conference presentations and workshops (Engage Liverpool, 2014b) enables residents' voices to be projected to a wide audience and to be heard by other agents of urban change. Critically, it is important to be able to listen to these voices including those who are 'hard to reach' as well as the more readily active contributors (Firelli et al. 2016). This is particularly the case at a time of global, national and city emphasis on sharing good practice, and to learn from each other about the interconnected themes of re-centralisation, city centre living, its quality and the identification of distinctive and inclusive neighbourhoods.

It is worth reiterating at this point that most of the places in which people live have no long- term residential history, whether new-build, regenerated or re-regenerated (Light and Speake 2000), as this theme underpins many of the subsequent narratives and provides insights for similar locations elsewhere. It shows too, that urban locations are not static but are constantly contested and transformed away from profit motives towards motives based on people's needs and interests. Within the context of enhancing the liveability of city centres to make them better places to be in, the following section considers observations made by Liverpool city centre residents and provides an example of the sorts of dialogue taking place between different stakeholders.

\section{Engaging the creative impulse}

In the name of authenticity and real world engagement, the words reflected upon here were those narrated in workshops organised by Engage for residents and key city change-makers at their Sixth Annual Conference in May 2013 on 
'Engaging the Creative Impulse'. Given global and local interest in liveability issues and Liverpool's aim to be a more 'liveable' city, focus here is on key discussion topics of the following workshops - 'Engage with your neighbourhood (unleashing the potential of distinctive neighbourhoods)' and 'Engage with your city (improving the quality of life in the city)'. The first author along with a research assistant took no part in facilitating the workshops. The first author provided the delegates with details about the research according to due process. Liverpool Hope University granted ethical approval for the project prior to the research. Given some movement in and out of workshops, at any one point the number of participants (residents and other key city-changers) in each of the workshops, varied between 12 and 15. The discussions in the workshops (four in total, two per key discussion topic) formed the basis of the subsequent thematic commentary (Aronson, 1994; Braun and Clarke, 2006). Chosen for its flexibility, the approach here uses the themes raised and covered by participants in the workshops (rather than researcher chosen).

The themes raised within the two workshops on each topic will be discussed on the following sections: Engage with your neighbourhood (unleashing the potential of distinctive neighbourhoods, and Engage with your neighbourhood (improving the quality of life in the city). Even though the regenerated neighbourhoods of the city centre and waterfront in Liverpool which are discussed are a result of the investment (capital accumulation) motive of property developers, it can be heard through the residents' voices that there is another process, the process of citizen's/residents' involvement which is trying to influence the context of the neoliberal regenerated neighbourhood setting. Residents' and other citizens' voices reflect concerns of the lack of community in the regenerated city centre which might be considered an implicit critique of neoliberal urbanism and, at the same time, reflect a vision of liveable city. [As an endnote: The anonymised voices are those of residents, unless otherwise indicated].

The themes raised within the two workshops on each topic will be discussed on the following sections: Engage with your neighbourhood (unleashing the potential of distinctive neighbourhoods, and Engage with your neighbourhood (improving the quality of life in the city). Even though the regenerated neighbourhoods of the city centre and waterfront in Liverpool which are discussed are a result of the investment (capital accumulation) motive of property developers, it can be heard through the residents' voices that there is another process, the process of citizen's/residents' involvement which is trying to influence the context of the neoliberal regenerated neighbourhood setting. Residents' and other citizens' voices reflect concerns of the lack of community in the regenerated city centre which might be considered an implicit critique of neoliberal urbanism and, at the same time, reflect a vision of liveable city. [As an endnote: The anonymised voices are those of residents, unless otherwise indicated].

\section{Engage with your neighbourhood (unleashing the potential of distinctive neighbourhoods)}

When asked 'what's your neighbourhood?' responses revolved around an emerging sense of community relating to self-identification, place distinctiveness and senses of belonging (or not) for example, saying [neighbourhood is]" just geography" and [it's] "not just residents who have to live somewhere and have to 
have a house but shopkeepers and people who you meet on a daily basis". Another, fuller description was:

"our neighbourhood is very defined geographically, I think of the four roads that border our neighbourhood but there's such diversity within that, there's businesses, there's restaurants, there's long term residents, there's people who are just renting, there's students, there are so are many different things there".

The complex nature of neighbourhood was apparent as people attempted to articulate what they understood by it. Sometimes residents' responses revealed immediate concerns such as "I live on the waterfront - it's isolated, I don't know anyone" and "places and the actual people are isolated from one another" or "I feel disconnected" or tried to rationalise it more, as in:

"It's really difficult, within certain city centre neighbourhoods, you don't see people, you don't meet people, there's no unifying thing. I know two people on the road where my building is based, and one of those is because they're the next door neighbours and we get their mail”.

Residents also reported that as people had to move for jobs, communities changed and new neighbourhoods had no or few bridges between their inhabitants. These comments were revealing in the sense that neighbourhood tended to be described in relative rather than absolute terms; relative to what neighbourhood 'ideally' should be. This observation was made in the clear and direct responses to the discussion point 'what is our ideal neighbourhood?' It was generally recognised that a neighbourhood is a neighbourhood regardless of its geographical location - it should be the 'full package' of facilities, have a clear 'street' environment, have green space, it should also be a place "where people know who lives there and a place which is welcoming". This was considered be difficult to attain in a short time, but that 'growing the neighbourhood' was important. Nevertheless, reinforcement of senses of neighbourhood included feeling responsibility for 'ownership' of place, creating a pleasant, welcoming 'micro' environment and a common cause and investment in something. It did not matter whether it was a common cause either 'for' or 'against' something. For example one resident thought that a proposed new supermarket development could be interpreted as "a swear word or catalyst to bring people together".

Residents generally considered that it was important for people to meet, even though they felt that "it's really difficult to get everyone together". There was also discussion about how to achieve this, including them not having to be formally "booted and suited - it can be in Tesco [supermarket]". The role of social media was considered, with some reflections about how to take "the technological kind of world and make it physical". People related examples of where social media had contributed to increasing connectivity through highlighting opportunities for face-to-face contact at gatherings such as 'The Big Lunch' and through the three successful 'Jane's Walks' (in the Baltic Triangle, Hope Street, and the Stanley Street Quarter in May 2013). Within the discussion about how do we [authors' emphasis] make connections so that people actually turn up at events was a pithy comment that, even in the world of social media, it 
was often one particular person who did it "since someone has to make it happen".

It was felt that this 'someone' could (and should) be 'anyone' and many examples were given of residents who were actively (if not overtly consciously) enhancing their neighbourhood through contributing to 'neighbourliness' in ways such as welcoming new residents, helping maintain and enhance the micro-environment through litter-picking, lining-up waste bins for collection etc. Sometimes this was done through a 'local kindness', and at others through more formally organised events. Here, the activities of Engage were referred to positively as in "Engage does a fantastic job. Engage is very unique, there's nothing like it in any other city". Neighbourliness was also thought to be enabled at a wider scale, by large city events (like the Liverpool Odyssey and The Tall Ships). Encouraging involvement was thought to empower and enable individuals "to make a difference". Revealingly, perhaps there was consensus that that this "could actually take some courage" (city centre entrepreneur) as there seemed to be a need to 'relearn' neighbourhood in new residential areas in the city centre and that this is, in fact, "a great challenge".

Significantly, in the case of central Liverpool this challenge is being taken up by a wide-range of stakeholders, including businesses. As one community business director observed about the Baltic Triangle:

"[I have] a very strong sentimental feeling for the neighbourhood as part of the process [area revitalisation] and I want to see that develop. I love that the kids have their skate-park and I love all those things. it's something kind of novel for businesses to go and get engaged in neighbourhoods in that way and that's something that all the way across the city there's a possibility of kind of making those connections, and it's an interesting angle for trying to build neighbourhood around businesses".

Subsequent narratives focussed on the nature of community venues, reporting how in the last decade, these seemed to have transitioned from public sector-led to a situation in which private sector, often small and medium enterprises (SMEs), play a leading role, "what seems to be emerging is all the cafés and bars and other venues are replacing that" (community business director). Critically, it was felt that community gathering places were emerging casually and organically and that these represented "the true sense of making community because you can choose to get involved in it" (rather than being 'made' and 'imposed' by external change-makers). A clear view was that "neighbourhood is more about what you need to support your life but then community is the feelings that you have about your life".

Furthermore, what works in one place does not necessarily work in another and that neighbourhoods should not need to be mirror images of each other. Thus, neighbourhood differences can reflect the responses and engagement of the community. This is exemplified by Camp and Furnace (unique event venue, restaurant and bar) "which only works in the Baltic Triangle" and Leaf (restaurant and multifunctional space) on Bold Street. 'Could and should residents be proactive in promoting local businesses?' - Strong and deep reflections were vocalised. Universally, the response was 'yes', but with difference in the detail about whether there should be the equal promotion of all businesses or more weighting towards local independent ones. In all, both were to be encouraged. 
Examples included independent businesses in the Baltic Triangle like the Baltic Bake House, Unit 51 (creative business start-up space and coffee shop) and the Elevator Studios (working spaces for artists and musicians - essentially a creative hub). Included within the rationales given was the importance of having a choice to be able to support local retailers and suppliers (with perhaps more expensive products) and also have access to the (often) cheaper products offered by larger, external businesses. As expressed directly by one city centre resident "in economic terms we need access to cheap things as well".

There was a general agreement about the importance "to keep as much money circulating in the city as possible". Some of the above comments suggest an implicit recognition between the exploitative character of big multinational corporations which transfer money outside where they operate and towards their central offices to be distributed to stakeholders. This seems to be suggested by the additional comments that "we want the money that Liverpool has ... to stay locally" or the role of advocacy for "the local, the ordinary people who are trying to make a living here ... and who provide distinctiveness to the neighbourhood". Some residents seemed to imply that a creative and constructive symbiosis between residents and businesses is important. However the nature of business which is important for the city is contested as some residents clearly support local business, despite the fact that their products might be more expensive, as this supports local jobs and local development rather than the exploitative labour relations that big corporations might have which result in cheaper products.

Nevertheless, some other participants focussed on the need to have cheaper products as well. This reflects a contested view of the nature of business. It also reflects the current practice in the city at the local government level to encourage these dialogues and also that residents should engage with businesses in the creation and maintenance of distinctive, liveable places. What the nature of these businesses might be though is contested.

This concern with the interconnectedness of different types of neighbours (particularly residents and businesses) in the creation of liveable places is in itself a notable characteristic of the approach to area revitalisation in central Liverpool. Also evidenced are the opinions of local people in non-traditionally residential areas, whose feelings and opinions about liveability are similar to the portrayals of successfully engaged, connected life at street level conveyed by the Monocle and other global liveable city comparator surveys. So, if people have chosen to live in Liverpool city centre and support it, then what do they suggest in terms of enhancing the experience of living in the city centre? These suggestions are reported and reflected upon in the following section.

\section{Engage with your neighbourhood (improving the quality of life in the city)}

Principally, people invest their lives [authors' emphasis] in Liverpool. Given this, many delegates commented that there is plenty of opportunity for more residents (and not just visitors) to be attracted to the revitalised and revitalising city. However, there is still work to be done in raising awareness of what the city already has, as well as enhancing the city's emerging reputation as a 'can do' place and good for city centre living. 
There was an opinion that people tend to find out information about living in the city centre and events that happen there, more or less by accident, although the virtual community in Liverpool is actually "pretty rich". One of the problems was the identification of effective ways of communication at a time of wide disparities in terms of access to the web-based materials. It was felt that encouraging people to endorse the city beyond the big campaigns such as 'It's Liverpool' and 'I'm Liverpool' (It's Liverpool, 2014) would help. Delegates thought that there was a real need for local inhabitants and visitors to spread the word about the diversity and creativity in the city centre, particularly its changing character since European Capital of Culture in 2008, the opening of Liverpool One (retail complex) and the large-scale, free cultural events which take place regularly. This strong feeling of pride in the city permeates the following resident's comment:

"I'm proud of the city I sing its praises everywhere we go, I like the idea of Liverpool being smart and publicising itself, I don't think that we've done well over the years and I think that Manchester overtook us in that aspect I think that we're getting better and have room to improve the publicising of the city".

Some of the thirty-year legacy of a troubled, rapid de-industrialisation of the city along with the negative labelling of Liverpool and the stereotyping of 'scousers' [people who come from Liverpool] (Bowland, 2008) still lingers in the public consciousness elsewhere in the UK, that "trying to live [it] down is a nightmare", and that the city continues to be "the butt for a lot of jokes". Such imagery, which part is socially constructed (Bowland, 2008), still often has to be challenged by alternative evidence that twenty-first century Liverpool is a green, cultural and innovative city.

This contrast between city reality and imagery was vividly described in the following description of a young north Londoner looking to buy a city centre property who absolutely "raved about the city, he spent the whole weekend here to research it and couldn't believe what he found compared to what he thought before he came" (housing manager).

One of the outcomes of the revitalisation of Liverpool city centre is that it has been so successful that many more people now choose to live there. There has also been a shift away from the default position of the last two decades in which city centre living was seen as a domain for transient students and young professional people (Couch et al., 2009; Rae, 2013) with its housing profile of largely one or two bedroom apartments (Liverpool Vision and Liverpool City Council, 2010). The city is has been looking globally, for example New York, to fact-find about alternative housing forms, including larger apartments for families. Such practice also reflects the city's overall approach articulated in the Strategic Investment Framework, of 'global review of what works in successful cities and what lessons can be taken forward in Liverpool' (Liverpool Vision, 2012, p. 2).

As in other cities (Seo, 2002; Allen and Blandy, 2004; Allen, 2007), there has been recognition and discussion about the advantages and disadvantages of catering for a wider residential social spectrum, particularly relating to providing accommodation types and amenities suitable for people at all life-cycle stages. Some of this dialogue has also taken place in the context of the city's 
ambitions for the next 15 years to create a more diversified residential population and to extend the range of the city centre housing (Liverpool Vision, 2012).

The emergence of a wider social stratification with families with children and older people in Liverpool city centre and those of different income streams highlights a changing situation in which the question is increasingly becoming not just how much people can afford to invest in the city centre financially, but how much they will engage with it. Listening to a diversity of voices is happening as stories of 'other' lives and interactions with the city are heard, for example about a:

"Family with two children and they've chosen to live in the city centre in an apartment and although it's crushed they really like it. They'd like to have a bigger apartment and look forward to the day when there will be some".

It was mooted that one of the characteristics of Liverpool city centre is that it does not have much social housing and that living in the city centre should not just be a lifestyle choice predominantly for the young and more affluent. This might suggest a desire to move beyond a regenerated city centre which predominantly benefits the affluent. It may therefore be a contestation of the neoliberal regenerated city centre and the unequal distribution of benefits within it. As Boland et al., (2017) have argued, regenerated cities within the confines of neoliberalism clearly raise questions of politics of distribution. There was a call by residents and representatives from residential property management teams to involve residents more fully in development decision making processes. The underpinning aims of this were to look at development from a user's perspective and to attempt to create, not just 'pattern book' apartments, but 'real' liveable spaces. In addition to standard questions about floor space and number of bedrooms, it was felt that developer should ask further questions relating to the delivery of purposeful, liveable space, for example:

"Has it [the development] got bike stores? Where are the bins? Where are they housed? How do you access them ... Is there a garden anywhere? Is there a communal facility?" (Housing manager)

What emerged very strongly was a view that developers should be encouraged to look more at their potential developments from this wider angle and provide opportunities for meaningful creativity, to it make them stack-up commercially, add value to the property and contribute to creating more 'truly' liveable spaces.

There was a plea for more "joined-up thinking, to consider city neighbourhoods in their totality", not just as buildings but also as ensembles with the spaces in-between. It was not only big scale issues that mattered, but smaller ones in which individuals could get involved and contribute to change making. At the level of improving street cleanliness, bins and litter residents thought that small scale, individual efforts would contribute to improving the urban environment as:

"the appearance of the city street cleaning and things like that, while they're only small things everybody sees the chewing gum, the cigarettes, the papers, and what 
have you and I think that that ought to be looked at - it's the small things that put people off".

Small group engagement with specific issues such as graffiti in Ropewalks, was considered important within the wider theme of people as 'overseers who support their area'. Again, people's individual relationships with local places were paramount in attempting to improve ordinary everyday lived life experiences. Engage Liverpool and local Community Interest Companies (CICs) in the Baltic Triangle and Stanley Street Quarter are in a good position to work with local residents and businesses to enhance liveability at this level.

However, one resident also pointed out that in the city centre "all of the different quarters, these [are] gonna rely on people who don't live there to support them". This is an obvious, but important observation to have made, as it expresses a wider conception of interrelationships between the perceived "shining city centre" and the suburbs as well as issues associated with 'ownership' of the central city. Another resident commented that they had:

"seen the city go through numerous phases and [now is] one of the best phases that I've personally been witness to, particularly all the wonderful, inspired things that are going on in the city. Different quarters and different developments are very good but so different to what you will encounter two steps down the road when you encounter streets and streets and streets of boarded up houses ... it's like two worlds".

This current intra-urban disparity in Liverpool has been the subject of much comment by the media and academics (e.g. Couch et al., 2009; Cocks and Crouch, 2012, Sykes et al., 2013) but lie beyond the remit of this paper. It is worth reporting though that the distinctive neighbourhood approach to enhancing liveability currently implemented in the city centre is to be rolled-out across the city as a whole.

The following concluding observations reflect upon the implications of listening to and hearing the voices of city centre residents. What they say about their interactions with the city and perspectives on the city through conduits such as Engage Liverpool furthers our understandings of the ways in which residents experience city centre living and contribute to change, which is a core theme of community development.

\section{Discussion and Concluding remarks}

Urban transition is influenced by global and local processes and is currently largely dominated by the forces of neoliberal capitalism. Cities are an outcome of, and mirror to, technological, economic, political and social shifts. As a consequence, cities and their central hubs are changing rapidly. City centres are at the sharp end of these changes and in many ways have been, and still are, foci for transformation, especially economic (Massey, 2007; Miles, 2007; Fainstein, 2010, 2016; Attuyer, 2015). Within this context, there has been more emphasis on cities and their city centres as places for profit not people (Brenner et al. 2009, 2011; Marcuse et al. 2011). Yet, accompanying neoliberal led city centre regeneration there has been increasing awareness that citizens who live and 
work in the city centre are important agents of change too and that their voices need to be heard and heeded.

Activating citizen participation in dialogue about their city can be a challenge (e.g. Aitken, 2012; Savini, 2011; Ferilli et al., 2016) and there is much to explore about how to engage people effectively in planning for a better, more just city. It is in this context that this paper presents the example of a citizen's initiative, Engage Liverpool, and its role in facilitating residents as urban change makers. It is apparent that these narratives tell of residents who live in the city centre and care about the quality of life there, that they know what living in this locality offers them and realise that their voices can contribute to the improvement of city centre living. Their discussions focussed on generating and maintaining neighbourhood distinctiveness and inclusiveness, improving and enhancing the local environment and raising the quality of life at street level. More explicitly, these observations expand what is known about what contributes to good urban liveability and build on the work of Sao, 2002; Allen, 2007; Couch et al., 2009, Howley and Clifford, 2009 to show what central city dwellers consider will improve their everyday lived lives and importantly, means by which their voices can be harnessed to implement change. It provides a unique example that expands knowledge and understanding about such forms of resident participation as a type of citizen participation. As such it has relevance across the social sciences from urban planning to social work.

This research also demonstrates how Engage Liverpool, one of the largest residents' associations in the $\mathrm{UK}$, is contributing substantially to community and neighbourhood capacity building. Accordingly, it provides an excellent example of a way to 'innovate from within' (Holden and Scerri, 2013, p. 452). It shows too, how senses of 'neighbourhood', 'community' and 'belonging' may be fostered in newly residential waterfront and city centre locations and how opportunities can be created for residents to 'embed' into their living-spaces and to enjoy being in the city. This is achieved through face-to-face and virtual meeting opportunities. It is shown how residents' voices and actions can be harnessed to make effective contributions to policy formulation and planning through multiway connections between the users and creators of city centres. Seminars, conferences and other events organised by Engage Liverpool (as well as other regeneration stakeholders such as Liverpool Vision) provide openings for city centre residents to contribute to developmental discussion about major initiatives such as the Liverpool City Centre Strategic Investment Framework (Liverpool Vision 2012). This is significant at a time when the population of the city centre in Liverpool is projected to become the largest in the UK (Liverpool Vision, 2012) and is now well on the way to becoming so.

Although it might be argued that such resident engagement may reflect "a superficial rhetoric of inclusion" (Ferilli, 2016:95), it nevertheless offers the potential for change. Always, more egalitarian and inclusive ways of participation should be explored (Ferilli, 2016; Arnstein, 1969).

The voices of city centre residents, rarely vocalised in a context of city centre change are reported here. This paper relates residents' contributions at the conference 'Engaging the Creative Impulse' in sessions on 'Engage with your neighbourhood (unleashing the potential of distinctive neighbourhoods)' and 'Engage with your city (improving the quality of life in the city)'. Their narra- 
tions contribute to the dialogue on the enhancement of city centre living, covering themes such as re-urbanisation, the quality of city centre living and issues linked to distinctive and inclusive neighbourhoods.

Contemporary city centre Liverpool has been shaped according to neoliberal lines and presents itself as vibrant and outward looking with a dynamic, revitalised commercial and cultural hub connected to the rest and best of the world. For over 30,000 people it is also where they live. Many live in former industrial locations with no residential tradition and in which senses of community and neighbourhood are only just evolving/being created. This paper asserts that despite the dominance of neoliberal development and the prevalence of the neoliberal discourse, neoliberalism it is not the only way of transforming a city and keeping it constantly reinvigorating, regenerating and re-regenerating. There are initiatives, such as those of Engage Liverpool which are not motivated by neoliberalism and its profit making, rather they aspire to improve the lives and enhance citizen participation in which residents are not consumers but citizens entitled to have a say and actively seek to have their voices heard in making cities better for people.

City centre regeneration needs to be explored not only through the constraints of a neoliberal city (Fainstein, 2010, 2016; Brenner et al., 2011) but also as a local reality and as people's own lived-space. This paper does this. The voices of the people who live in the city centre and participated in the workshops contest the neoliberal city as they recognise the alienation and the lack of community and belongingness that is inherent to neoliberalism but at the same time are concerned about building community and making the city centre a liveable place for everyone. This is a process that is just beginning. It is a process motivated by a perceived 'altruistic local kindness'. It is also a process inspired by the vision of the people of what a neighbourhood ideally should be. This vision also contests the neoliberal city. However, clear strategies of contestation have not been articulated yet. There is diversity in residents' opinions and which view(s) will prevail and influence the city development remains to be seen.

\section{Acknowledgements}

The authors thank Gerry Proctor, Vivien Fox, Mark Whitfield and the participants for their contributions to this project.

\section{References}

Aitchison, C, Richards, G \& Tallon, A (eds) 2007, Urban transformations: regeneration and renewal through leisure and tourism, Leisure Studies Association, Eastbourne.

Aitken, D 2012, Trust and participation in urban regeneration', People, Place and Policy, vol. 6, no. 3, pp. 133-147.

Allen, C 2007, 'Of urban entrepreneurs or 24-hour party people? City-centre living in Manchester, England', Environment and Planning, vol. 39, no. 3, pp. 666-683.

Allen, C \& Blandy, S 2004, The future of city centre living: implications for urban policy, Centre for Regional Economic and Social Research Sheffield Hallam University, 
Sheffield.

Antonini, M, Hogg, MA, Mannetti, L, Barbieri, B \& Wagoner, JA 2015, 'Motivating citizens to participate in public policymaking: Identification, trust and costbenefit

analyses', Journal of Social and Political Psychology, vol. 3, no. 2, pp. 131-147.

Aronson, J 1994, A pragmatic view of thematic analysis, viewed 2 January 2014, http://www.nova.edu/ssss/QR/BackIssues/QR2-1/aronson.html.

Arnstein, SR 1969, 'A ladder of citizen participation', Journal of the American Institute of Planners, vol. 35, no. 4, pp. 216-224.

Attuyer, K 2015, 'When conflict strikes: contesting neoliberal urbanism outside participatory structures in inner-city Dublin', International Journal of Urban and Regional Research, vol. 39, no. 4, pp. 807-823.

Avraham, E \& Kettner, E 2008, Media strategies for marketing places in crisis: improving the image of cities, countries and tourist destinations, Butterworth-Heinemann, Oxford.

Bianchini, F \& Ghilardi, L 2004, The culture of neighbourhood: a European perspective, in D Bell \& M Jayne (eds), City of quarters: urban villages in the contemporary city, pp. 237-245, Ashgate, Aldershot.

Biddulph, M 2010, 'Liverpool 2008: Liverpool's vision and the decade of cranes', in J Punter (wd), Urban design and the British urban renaissance, pp. 100-114, Routledge, London.

Blanchet-Cohen, N 2014, 'Igniting citizen participation in creating healthy built environments: the role of community organizations', Community Development Journal, vol. 50, no. 2, pp. 264-279.

Boddy, M \& Parkinson, M (eds) 2004, City matters: competitiveness, cohesion and urban governance, Policy Press. Bristol.

Boland, P 2008, The construction of images of people and place: labelling Liverpool and stereotyping scousers', Cities, vol. 25, no. 6, pp. 355-369.

Boland, P 2010, 'Capital of culture - You must be having a laugh! Challenging the official rhetoric of Liverpool as the 2008 European cultural capital', Social and Cultural Geography, vol. 11, no. 7, pp. 627-645.

Boland, P, Bronte, J \& Muir, J 2017, 'On the waterfront: neoliberal urbanism and the politics of public benefit', Cities, vol. 61, pp. 117-127.

Braun, V \& Clarke, V 2006, 'Using thematic analysis in psychology', Qualitative Research in Psychology, vol. 3, pp. 77-101.

Brenner, N, Marcuse, P \& Mayer, M 2009, Cities for people, not profit, introduction', City, vol. 132-133, pp. 176-184.

Brenner, N., Marcuse, P. and Mayer, M. (2011). Cities for people, not for profit: critical urban theory and the right to the city. London: Routledge.

Bromley, RDF, Tallon, AR \& Roberts, AJ 2007, New populations in the British city centre: evidence of social change from the census and household surveys', Geoforum, vol. 38, no. 1, pp. 138-154.

Brudell, P \& Attuyer, K 2014, 'Neoliberal 'regeneration' and the myth of community participation', in A Maclaran \& S Kelly (eds), Neoliberal urban policy and the transformation of the city: reshaping Dublin, Palgrave Macmillan, Basingstoke.

Bruns-Berentelg, J 2011, 'Social mix and encounter capacity - a pragmatic social model for a new downtown: the example of HafenCity, Hamburg', in G Bridge, T Butler, L Lees (eds), Mixed communities, gentrification by stealth?, pp.69-94, Policy 
Press, Bristol.

Buck, N, Gordon, I, Harding, A \& Turok, I (eds) 2005, Changing cities: rethinking urban competitiveness, cohesion and government, Palgrave Macmillan, Basingstoke.

CLG 2006, State of English cities: Social cohesion, CLG (Communities and Local Government), London.

Cochrane, A 2007, Understanding urban policy: a critical approach, Blackwell, Oxford.

Cocks, M 2013, 'Conceptualising the role of key individuals in urban governance:

Cases from the economic regeneration of Liverpool, UK', European Planning Studies, vol. 21, pp. 575-595.

Cocks, M \& Crouch, C 2012, The governance of a shrinking city: Housing renewal in the Liverpool conurbation, UK, International Planning Studies, vol. 17, no. 3, pp. 277-301.

Cohen, S 2007, Decline, renewal and the city in popular music culture: Beyond the Beatles, Ashgate, Abingdon.

Colomb, C 2007, 'Unpacking New Labour's 'urban renaissance' agenda: towards a socially sustainable reurbanization of British cities?', Planning, Practice and Research, vol. 22, no. 1, pp 1-24.

Connolly, MG 2013, The 'Liverpool Model(s)': cultural planning, Liverpool and Capital of Culture 2008, International Journal of Cultural Policy, vol. 19, no. 2, pp. 162-181.

Couch, C \& Dennemann, A 2000, 'Urban regeneration and sustainable development in Britain: the example of the Liverpool Ropewalks Partnership', Cities, vol. 17, pp. 137-147.

Couch, C 2003, City of change and challenge: urban planning and regeneration in Liverpool, Ashgate, Aldershot.

Couch, C \& Cocks, M 2012, From long-term shrinkage to re-growth? The urban development trajectories of Liverpool and Leipzig,, Built Environment, vol. 38, no. 2, pp. 162-178.

Couch, C, Fowles, S \& Karecha, J 2009, 'Reurbanization and housing markets in the central and inner areas of Liverpool', Planning Practice and Research, vol. 24, no. 3 , pp. 321-141.

Cox, T \& O'Brien, D 2012, The "scouse wedding" and other myths: reflections on the evolution of a "Liverpool model" for culture-led urban regeneration', Cultural Trends, vol. 21, no. 2, pp. 93-101.

Davidson, M \& Lees, L 2005, New-build "gentrification" and London's riverside renaissance', Environment and Planning A, vol. 37, no. 7, pp. 1165-1 190.

Du Noyer, P 2002, Liverpool: Wondrous place. Music from Cavern to Cream, Virgin Books, London.

Engage Liverpool 2014a, Engage Liverpool neighbourhoods, viewed 2 January 2014, https://goo.gl/IPAI77.

Engage Liverpool 2014b, Engage Liverpool, viewed 2 January 2014, https://goo.gl/0Vyh0g.

Engage Liverpool 2017, Engage Liverpool mission statement, viewed 20 April 2017, https://goo.gl/PbYmks.

Fainstein, S 2001, Competitiveness, cohesion and governance: their implications for social justice', International Journal of Urban and Regional Research, vol. 25, no. 4, pp. 884-888.

Fainstein, S 2010, The just city, Cornell University Press, New York. 
Fainstein, S 2016, 'Financialisation and justice in the city: a commentary', Urban Studies, vol. 53, no. 7, pp. 1503-1508.

Ferilli, G, Sacco, PL \& Blessi, GT 2016, 'Beyond the rhetoric of participation: new challenges and prospects for inclusive urban regeneration', City, Culture and Society, vol. 7, pp. 95-100.

Foord, J 2010, Mixed-use trade-offs: how to live and work in a compact city neighbourhood', Built Environment, vol. 36, no. 1, pp. 47-62.

Frost, D \& Phillips, R (eds) 2011, Liverpool '81: remembering the Toxteth Riots, Liverpool University Press, Liverpool.

Garcia, B, Melville, R \& Cox, T 2010, Creating an impact: Liverpool's experience as European capital of culture, University of Liverpool and Liverpool John Moores University, Liverpool, viewed 2 January 2014, https://goo.gl/O5omcu.

Gehl, J 2010, The lively city, Island Press, Washington DC.

Gehl, J 2011, 'Copenhagen: showcasing sustainability. Discussion 01', Monocle, vol. 45 , pp. 39.

Gold, J \& Gold, M 2005, Cities of culture: staging international festivals and the urban agenda 1851-2000, Ashgate, Aldershot.

Gold, J \& Gold, M (eds) 2007, Olympic cities: city agendas, planning and the world's games 1896-2012, Routledge, London.

Gramsci, A 1971, The prison notebooks, Lawrence and Wilshaw Press, London.

HafenCity Hamburg 2012, HafenCity Hamburg, viewed 2 January 2014, https://goo.gl/HqVvJq.

Halbert, L \& Attuyer, K 2016, 'Introduction: The financialisation of urban production: conditions, mediations and transformations', Urban Studies, vol. 53, no. 7, pp. 1347-1361.

Hall, T \& Hubbard, P (eds) 1998, The entrepreneurial city: geographies of politics, regime and representation, Wiley, Chichester.

Harvey, D 1989, 'From managerialism to entrepreneurialism: the transformation of governance in late capitalism, Geografiska Annaler, vol. 71, no. B, pp. 3-17.

Harvey, D 2005, Spaces of neoliberalization: towards a theory of uneven geographical development (Vol. 8), Franz Steiner Verlag, Stuttgart.

Harvey, D 2012, Rebel cities: from the right to the city to the urban revolution, Verso Books, London.

Heeg, S 2011, 'Flows of capital and fixity of bricks in the built environment of Boston: Property-led development in urban planning?' in G Desfor, J Laidley, Q Stevens \& D Schubert (eds), Transforming urban waterfronts: fixity and flow, pp. 274294, Routledge, London.

Hofseth, M 2008, The new opera house in Oslo - a boost for urban development', Urban Research and Practice, vol. 1, no. 1, pp. 101-103.

Holden, M \& Scerri, A 2013, More than this: liveable Melbourne meets liveable Vancouver', Cities, vol. 31, pp. 444-453.

Howley, P 2010, 'Sustainability v liveability: an exploration of central city housing satisfaction', International Journal of Housing Policy, vol. 10, no. 2, pp. 173-189.

Howley, P \& Clifford, B 2009, The transformation of inner Dublin: exploring new residential populations within the inner city', Irish Geography, vol. 42, no. 2, pp. 225-243.

Howley, P, Scott, M \& Redmond, D 2009, 'Sustainability versus liveability: an investigation of neighbourhood satisfaction', Journal of Environmental Planning 
and Management, vol. 52, no. 6, pp. 847-864.

Howley, P 2010, Sustainability v liveability: an exploration of central city housing satisfaction', International Journal of Housing Policy, vol. 10, no. 2, pp. 173-189.

Hudson, M \& Hawkins, N 2006, 'A tale of two cities - a commentary on historic and current marketing strategies used by the Liverpool and Glasgow regions', Place Branding, vol. 2, no. 2, pp. 155-176.

It's Liverpool 2014 , It's Liverpool, viewed 2 January 2014 , http://www.itsliverpool.com/.

Jacobs, B \& Dutton, C 2000, 'Social and community issues', in P Roberts \& H Sykes (eds), Urban regeneration: a handbook, pp. 109-129, Sage, London.

Jane's Walks 2014, Jane's Walk, viewed 2 January 2014, http://www.janeswalk.net/.

Jessop, B \& Sum, NL 2000, 'An entrepreneurial city in action: Hong Kong's emerging strategies in and for (inter) urban competition', Urban Studies, vol. 37, no. 12, pp. 2287-2313.

Jones, AL 2007, 'On the water's edge: developing cultural regeneration paradigms for urban waterfronts', in MK Smith (ed), Tourism, culture and regeneration, pp.143150, CABI International, Wallingford.

Jones, P 2003, 'Urban regeneration's poisoned chalice: is there an impasse in (community) participation-based policy?', Urban Studies, vol. 40, no. 3, pp. 581601.

Jones, P \& Wilks-Heeg, S 2004, 'Capitalising culture: Liverpool 2008, Local Economy, vol. 19, no. 4, pp. 341-360.

Kirst-Ashman, KK \& Hull, GH Jr. 2001, Generalist practice with organizations and communities, Wadsworth/Thomson Learning, Belmont, CA.

Knox, P 2011, Cities and design. Critical introductions to urbanism and the city, Routledge, London.

Lees, L 2007, Gentrification, Taylor and Francis, London.

Lees, L 2008, Gentrification and social mixing: towards an inclusive urban renaissance?', Urban Studies, vol. 45, no. 12, pp. 2449-2509.

Legacy, C 2016, 'Is there a crisis of participatory planning?', Planning Theory.

Light, D \& Speake, J 2000, 'Heritage tourism and urban regeneration: a sustainable solution, in I Ianos, D Pumain \& JB Racine (eds), Integrated urban systems and sustainability of urban life, pp. 101-114, International Geographical Union Commission on Urban Development and Urban Life, Editura Tehnică, Bucharest.

Littlefield, D 2009, Liverpool One: remaking a city centre, Wiley, Chichester.

Liverpool City Council 2011, Stanley Street: strategic direction for a vital urban quarter. Final Report, May 2011, viewed 2 January 2014, https://goo.gl/Wg9Tu 1.

Liverpool City Council 2016, Key statistics bulletin issue 25 (September), Liverpool City Council, Liverpool.

Liverpool Vision 2011, United Nations praises Liverpool for sustainable development, viewed 2 January 2014, https://goo.gl/eIx3Sg.

Liverpool Vision 2012, Liverpool city centre strategic investment framework, Liverpool Vision, Liverpool.

Liverpool Vision 2016, City centre residential update, Liverpool Vision, Liverpool.

Liverpool Vision and Liverpool City Council 2010, City centre living: residential development update, PMD 481 March 2010, Liverpool Vision and Liverpool City Council. Liverpool. 
Mannarini, T \& Talò, C 2013, Evaluating public participation: instruments and implications for citizen involvement, Community Development, vol. 44, no. 2, pp. 239-256.

Marcuse, P, Connolly, J, Novy, J, Olivo, I \& Potter, C (eds) 2011, Searching for the just city, Taylor and Francis, London.

Marquardt, N, Füller, H, Glasze, G \& Pütz, R 2013, Shaping the urban renaissance: new-build luxury developments in Berlin', Urban Studies, vol. 50, no. 8, pp. 15401556.

McNeill, D 2011, Fine grain, global city: Jan Gehl, public space and commercial culture in central Sydney', Journal of Urban Design, vol. 16, no. 2, pp. 161-178.

Massey, D 2007, World city, Polity Press, Cambridge.

Meade, R 2005, 'We hate it here, please let us stay! Irish social partnership and the community/involuntary sector's conflicted experiences of recognition', Critical Social Policy, vol. 25, no. 3, pp. 349-73.

Meegan, R 2003, 'Urban regeneration, politics and social cohesion: the Liverpool case', in R Munck (ed), Reinventing the city? Liverpool in comparative perspective, pp. 53-79, Liverpool University Press, Liverpool.

Miles, M 2007, Cities and cultures: critical introductions to urbanism and the city, Routledge, London.

Monocle 2013, 'Global city ranking, Monocle, vol. 65, no. 7, pp. 32-51.

Morris, R \& Speake, J 2010, Liverpool: a case study of rebranding', Geography Review, vol. 23, no. 3, pp. 14-18.

Nevin, B 2010, 'Housing market renewal in Liverpool: locating the gentrification debate in history, context and evidence, Housing Studies, vol. 25, no. 5, pp. 715733.

New Urbanism 2014, Creating sustainable communities, viewed 2 January 2014, https://goo.gl/EaUdLv.

Oatley, N 1998, Cities, economic competition and urban policy, Paul Chapman, London.

Ohmer, ML 2007, 'Citizen participation in neighbourhood organizations and its relationship to volunteers' self- and collective efficacy and sense of community', Social Work Research, vol. 31, no. 2, pp. 109-120.

Pentaraki, M \& Speake, J 2015, Reclaiming hope within the geopolitics of economic bullying: the case of SYRIZA and post referendum Greece, AntipodeFoundation.org, 20, viewed 19 April 2017, https://goo.gl/tlq271.

Plaza, B 2006, The return on investment of the Guggenheim Museum, Bilbao, International Journal of Urban and Regional Research, vol. 30, no. 2, pp. 452-467.

Rae, A 2013, English urban policy and the return to the city: a decade of growth 2001-2011', Cities, vol. 32, pp. 94-101.

Roberts, M 2007, Sharing space: urban design and social mixing in mixed income new communities', Planning Theory and Practice, vol. 8, no. 2, pp. 183-204.

Rogers, R \& Power, A 2000, Cities for a small country, Faber and Faber, London.

Sassen, S 2012, Cities in a world economy, Sage, Thousand Oaks.

Savini, F 2011, The endowment of community participation: institutional settings in two urban regeneration projects', International Journal of Urban and Regional Research, vol. 35, pp. 949-968.

Scharenberg, A \& Bader, I 2009, 'Berlin's waterfront site struggle', City, vol. 13, no. 2-3, pp. 325-335.

Scott, AJ 2008, Resurgent metropolis: economy, society and urbanization in an 
interconnected world', International Journal of Urban and Regional Research, vol. 32, pp. 548-562.

Seo, JK 2002, 'Re-urbanisation in regenerated areas of Manchester and Glasgow: new residents and the problems of sustainability', Cities, vol. 19, pp. 113-121.

Smith, A 2012, Events and urban regeneration: the strategic use of events to revitalise cities, Routledge, London.

Smith, H \& Soledad Garcia Ferrari, M 2012, Waterfront regeneration: experiences in city-building, Routledge, London.

Speake, J 2016, 'Urban development and visual culture: commodifying the gaze in the regeneration of Tigné Point, Malta', Urban Studies.

Speake, J \& Fox, V 2006, Liverpool: discovering cities, Geographical Association, Sheffield.

Sykes, O, Brown, J, Cocks, M, Shaw, D \& Couch, C 2013, 'A city profile of Liverpool', Cities, vol. 35, pp. 299-318.

Tallon, A 2010, Urban regeneration in the UK, Routledge, London.

Teloni, DD \& Adam, S 2016, Solidarity clinics and social work in the era of crisis in Greece', International Social Work.

UN-Habitat 2014, I'm a city changer, viewed 2 January 2014, https://goo.gl/ki0FMV.

Unsworth, R 2009, 'City living and sustainable development: the experience of a UK regional city', Town Planning Review, vol. 78, no. 6, pp. 725-747.

Waley, P 2006, Re-scripting the city: Tokyo from ugly duckling to cool cat', Japan Forum, vol. 18, pp. 361-380.

Ward, K 2003, 'Entrepreneurial urbanism, state restructuring and civilizing 'New' East Manchester, Area, vol. 5, no. 2, pp. 116-137.

Wilks-Heeg, S 2003, From world city to Pariah city? Liverpool and the global economy 1850-2000', in R Munck (ed), Reinventing the City. Liverpool in Comparative Perspective, pp. 36-52, Liverpool University Press, Liverpool. 